\title{
Posidonia residues can be used as organic mulch and soil amendment for lettuce and tomato production
}

\author{
Francesco Grassi • Marcello Mastrorilli • Carlo Mininni • \\ Angelo Parente - Angelo Santino • Marcello Scarcella • \\ Pietro Santamaria
}

Accepted: 10 November 2014 / Published online: 3 December 2014

(C) INRA and Springer-Verlag France 2014

\begin{abstract}
There is a need for sustainable fertilizers because common mineral fertilizers are increasingly costly and often induce water and air pollution. For instance, seagrass compost could be used as fertilizer in the coastal areas of the Mediterranean, thus also solving the issue of beached residues. Here, we studied organic fertilization by application of seagrass-based compost in a tomato and lettuce crop succession. Composts were made of posidonia and yard wastes at
\end{abstract}

\section{F. Grassi · P. Santamaria}

Dipartimento di Scienze Agro-Ambientali e Territoriali, Università

degli Studi di Bari “Aldo Moro", Via Amendola, 165/A, 70126

Bari, Italy

F. Grassi

e-mail: francesco.grassi300@gmail.com

P. Santamaria

e-mail: pietro.santamaria@uniba.it

M. Mastrorilli $(\bowtie) \cdot$ M. Scarcella

Consiglio per la Ricerca e la Sperimentazione in Agricoltura,

Unità di ricerca per i sistemi colturali degli ambienti caldo-aridi

(CRA-SCA), Via C. Ulpiani 5, 70125 Bari, Italy

e-mail: marcello.mastrorilli@entecra.it

M. Scarcella

e-mail: marcello.scarcella@entecra.it

\section{Mininni $\cdot$ A. Parente}

Istituto di Scienze delle Produzioni Alimentari (ISPA),

Consiglio Nazionale delle Ricerche (CNR),

via Amendola 122, 70126 Bari, Italy

C. Mininni

e-mail: carlo.mininni@ispa.cnr.it

A. Parente

e-mail: angelo.parente@ispa.cnr.it

\section{A. Santino}

Istituto di Scienze delle Produzioni Alimentari (ISPA),

Consiglio Nazionale delle Ricerche (CNR),

via Monteroni, 73100 Lecce, Italy

e-mail: angelo.santino@ispa.cnr.it
$1 / 4 w / w$ fresh weight ratio. Compost was applied at two concentrations: 10 and $20 \mathrm{Mg} \mathrm{ha}^{-1}$ fresh weight. Fresh leaves of posidonia were also tested directly as organic mulch in plots treated with conventional fertilizers. A control treatment involved mineral fertilization without mulching soil. Herbicide applications were performed in non-mulched plots immediately before transplanting of tomato and lettuce for controlling the weeds, while mulched treatments did not receive any herbicide application. Results show that $20 \mathrm{Mg} \mathrm{ha}^{-1}$ of posidonia-based compost is equivalent to the inorganic fertilization because the nutritional status and yield of tomato and lettuce were statistically similar. No phytotoxicity symptoms were observed in any of the tomato and lettuce plants mulched with posidonia. The same growth rate was observed for tomato and lettuce growing under conventional management practices: mineral fertilizer and herbicide applications. Overall, our findings show that seagrass-based compost is a promising, sustainable fertilizer for tomato and lettuce.

Keywords Organic farming · Composting process and compost application - Organic fertilization - Organic mulch · Sustainable development . Crop rotations and management . Seagrass compost

\section{Introduction}

In recent years, interest in sustainable agricultural practices has grown with the aim of reducing potential environmental impacts of chemical herbicides and mineral fertilizers (Montemurro and Maiorana 2007). In this context, the use of organic soil amendments can influence soil fertility and plant health (Pinamonti 1998; Montemurro et al. 2005). The use of compost has been associated with desirable soil properties including higher plant available water holding capacity and lower bulk density (Pinamonti 1998) and can foster beneficial 
microorganisms (Bulluck et al. 2002), while organic mulching directly provides soil organic matter inputs to soil and has been used to effectively suppress weeds and reduce soil erosion in organic farming systems (Bilalis et al. 2003). In addition, organic mulch is also effective in conserving soil moisture and buffering drastic changes in soil temperature (Pinamonti 1998; Bulluck et al. 2002), which can be of special importance in sandy soils where large fluctuations of soil moisture and temperature often occur. Numerous studies report the potential convenience in using of diverse cover crop mulch in field vegetable production (Abdul-Baki et al. 1996; Rice et al. 2001; Tu et al. 2006; Campiglia et al. 2010).

In the Mediterranean regions, beached residues of the marine plant posidonia (Posidonia oceanica (L.) Delile) could be used as mulch media and the resulting compost could be an alternative to conventional fertilizers. The addition of compost not only could improve the physical and nutritional conditions of local soil (Diacono and Montemurro 2010), but also could solve the environmental problem of accumulation on the coasts (Castaldi and Melis 2002; Mininni et al. 2013).

A survey conducted in March-May, 2008, on 11 sites along the Apulia coastline, estimated more than $28,000 \mathrm{~m}^{3}$ of beach-cast residues concentrated in only about $4 \mathrm{~km}$ of touristic beaches, ports, and esplanades. The presence of high amounts of residues close to urban centers may represent a hardship because of the odors that develop from the accumulation or even a danger because of the possibility of fires, with consequent problems of public health and safety (Parente et al. 2013). In all these cases, the coastal municipalities are forced to remove seaweed residues (Fig. 1) that, in the absence of alternative solutions, are disposed of in landfills resulting in both environmental charges, due to the significant amount of organic matter removed from the ecosystem, and economic due to disposal costs (Castaldi et al. 2004). According to the literature, this problem is observed for other seagrasses and seaweeds in several countries (Kirkman and Hendrick 1997; Ochieng and Erftemeijer 1999).
In the Mediterranean basin, farmers used to collect posidonia residues from the seaboard for mulching their crops or for plugging seaweeds into the soils. The costs required by the use of this material result only from the carriage and the washing process, which is necessary before any use in order to remove sodium $\left(\mathrm{Na}^{+}\right)$and chloride $\left(\mathrm{Cl}^{-}\right)$ions that are present at high levels (Serio et al. 2004). In Italy, the possibility of using the seagrass as a raw material for composting is recent. With the Legislative Decree no. 75 of 29 April 2010, this material is allowed in the composition of the mixtures, although at a maximum of $20 \%$ by weight.

Some works have been conducted in order to evaluate the use of posidonia compost for biological control of pests (Kouki et al. 2012) and as partial substitute to peat in greenhouse vegetable productions (Mininni et al. 2013). Castaldi et al. (2004) studied the effects of composts obtained from sewage sludge and posidonia mixed in different proportions on soil properties and growth of lettuce (Lactuca sativa L.) plants.

The aim of the present work was to evaluate posidoniabased compost as soil amendment and beached residues as organic mulch material in a tomato (Solanum lycopersicum L.) and lettuce crop succession, in order to propose further utilization of this organic material for the development of sustainable agricultural practices.

\section{Materials and methods}

\subsection{Field site description}

The study was carried out in the farm of the "Agricultural Research Council" (CRA) situated in Monteroni di Lecce, Italy ( $40^{\circ} 19^{\prime}$ lat $\mathrm{N}, 18^{\circ} 5^{\prime}$ long $\mathrm{E}$, alt. $30 \mathrm{~m}$ a.s.l.) from May 2011 to April 2012 with two consecutive crops: tomato and oak leaf lettuce. The mean annual temperature of the area is
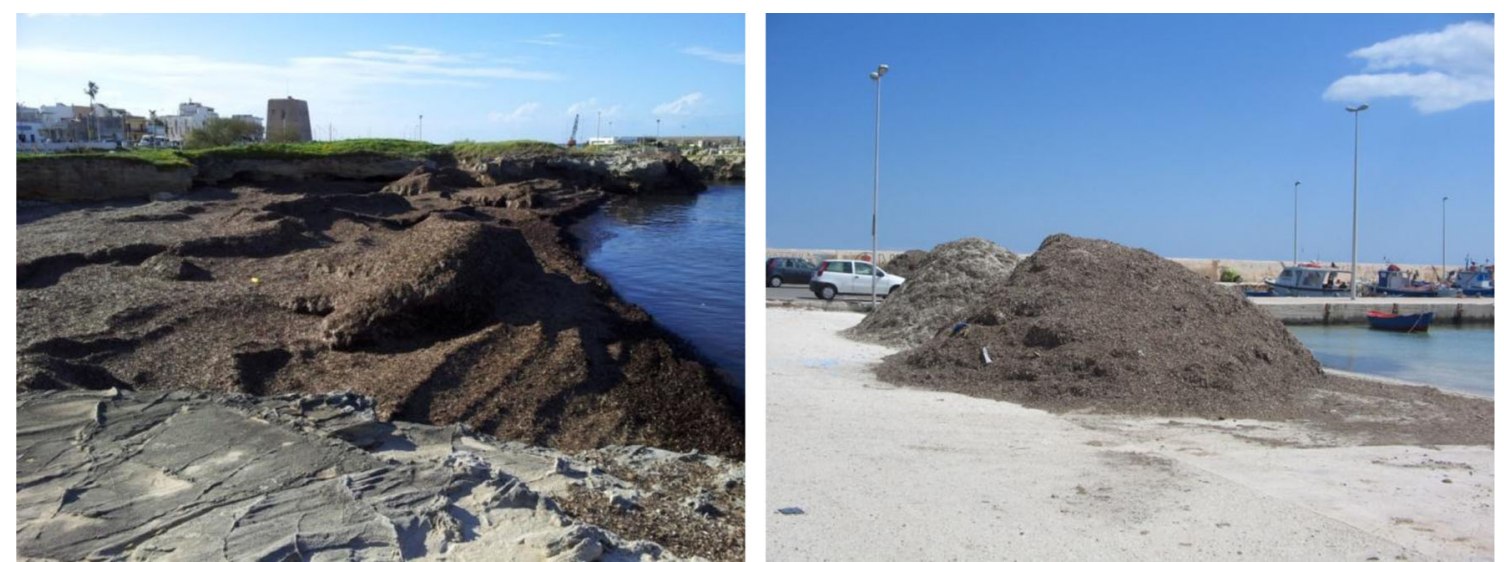

Fig. 1 Posidonia residues cause problems to coastal municipalities that are forced to remove them and to disposed in landfills resulting in both environmental and economic charges, due to the loss of organic matter and disposal costs 
$16.7^{\circ} \mathrm{C}$, and the mean annual precipitation is approximately $700 \mathrm{~mm}$. The climate of the region is a typical Mediterranean climate with rainfall predominately in the period OctoberApril. The main characteristics of the soil used for the experiment were as follows: sandy loam texture (sand, $654 \mathrm{~g} \mathrm{~kg}^{-1}$; silt, $181 \mathrm{~g} \mathrm{~kg}^{-1}$; clay, $165 \mathrm{~g} \mathrm{~kg}^{-1}$ ) with low values of cation exchangeable capacity $\left(9.8 \mathrm{cmol} \mathrm{kg}^{-1}\right)$ and of electrical conductivity $\left(0.26 \mathrm{dS} \mathrm{m} \mathrm{m}^{-1}\right)$. Nitrogen content obtained by the

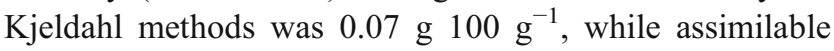
phosphorus (Olsen method) and exchangeable potassium $\left(\mathrm{BaCl}_{2}\right.$ method) were 11.4 and $156 \mathrm{mg} \mathrm{kg}^{-1}$, respectively. Water availability was low (field capacity, $15.0 \%$; wilting point, $8.5 \%$; available water, $6.5 \%$ ), due to the low organic

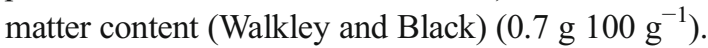

\subsection{Experimental setup}

The cropping cycle started with tomato in summer, and it continued with oak leaf lettuce in winter. Two hybrid cultivars were used for each crop: 'Colt' and 'Pizzico' (ISI Sementi s.r.l., Fidenza, Parma, Italy) for tomato and 'Ribaï' and 'Kipling' (Rijk Zwaan Italia s.r.l., Calderara di Reno, Bologna, Italy) for lettuce.

In each field experiment, the following four treatments were compared:

1. Mulched soil with fresh beached leaves of posidonia and mineral fertilization (mulched)

2. Organic fertilization with $10 \mathrm{Mg} \mathrm{ha}^{-1}$ of posidonia-based compost (fresh weight), non-mulched soil (OF10)

3. Organic fertilization with $20 \mathrm{Mg} \mathrm{ha}^{-1}$ of posidonia-based compost (fresh weight), non-mulched soil (OF20)

4. Mineral fertilization, non-mulched soil (MF)

The experimental design was a split-plot with two cultivars and four treatments, with three replicate blocks, where the cultivar was the main factor and the agronomic practice the subfactor. The main plot size was $200 \mathrm{~m}^{2}, 20 \mathrm{~m} \times 10 \mathrm{~m}$. The lettuce was grown in the same plots of tomato, and the same arrangement of treatments was maintained for both species.

\subsection{The posidonia residues}

Posidonia was used in field for soil mulching or amending after previous treatments.

Mulch Posidonia leaves were collected on 2011 March 15 from Port Adriano on the Adriatic Sea, San Cataldo (40 $39^{\prime}$ lat N, $18^{\circ} 30^{\prime}$ long E) and on 2011 September 20 from Sant'Isidoro beach on the Ionian Sea $\left(40^{\circ} 21^{\prime}\right.$ lat N, $17^{\circ} 92^{\prime}$ long E). The offshore residues were transported to the experimental farm and washed with water having low conductivity $(890 \mu \mathrm{S} / \mathrm{cm})$ in order to prevent a possible negative influence of sodium chloride $(\mathrm{NaCl})$ and to remove the sand particles.
The washing process was repeated four times using a ratio water/fresh beached leaves 1:1 $(v / v)$. Electrical conductivity (EC) and $\mathrm{pH}$ of four replications were monitored periodically in drainage water in each wash cycle. $\mathrm{Na}^{+}$and $\mathrm{Cl}^{-}$in drainage water were measured. After four washings, $300 \mathrm{~kg}$ of posidonia offshore residues (corresponding to $60 \mathrm{t} \mathrm{ha}^{-1}$ ) was distributed manually on the subplot soil and a 50-mm mulch layer was obtained.

Amendant The compost used in this study was obtained experimentally from a private composting plant (Progeva s.r.l., Laterza, Taranto, Italy) that used as raw material beached residues of the marine plant posidonia and yard wastes at a 1:4 $w / w$ (fresh weight) ratio. The mixtures were prepared respecting the microbial requirements of compost in terms of carbon/ nitrogen (35 to 45 ) and moisture content (55 to $65 \%$ ). Composting process took place in a pile $(1.5 \mathrm{~m}$ of height and $3 \mathrm{~m}$ of diameter); the temperature of the windrow was kept $>55{ }^{\circ} \mathrm{C}$ for at least 3 days, by turning and irrigating the piles periodically to obtain the pasteurization of the biomass. The active phase of composting was considered completed after 4 weeks, when the temperature of the pile decreased naturally to a value less than $40{ }^{\circ} \mathrm{C}$. The curing phase was characterized by less frequent turning and continued until the 90th day to achieve further stabilization and obtain the final product.

Table 1 Physical and chemical features of compost (on total compostable dry matter) and beached posidonia leaves

\begin{tabular}{|c|c|c|}
\hline & Posidonia compost & Raw leaves \\
\hline Humidity (\%) & 22 & 71 \\
\hline $\mathrm{pH}$ & $8.1 \pm 0.2$ & $8.2 \pm 0.2$ \\
\hline $\mathrm{EC}\left(\mathrm{dS} \mathrm{m} \mathrm{m}^{-1}\right)$ & $2.1 \pm 0.2$ & $12.5 \pm 0.2$ \\
\hline Total organic $\mathrm{C}\left(\mathrm{g} 100 \mathrm{~g}^{-1}\right)$ & $27.6 \pm 0.4$ & $35.5 \pm 0.27$ \\
\hline Total N (g $\left.100 \mathrm{~g}^{-1}\right)$ & $1.4 \pm 0.01$ & $1.2 \pm 0.02$ \\
\hline $\mathrm{C} / \mathrm{N}$ & 19.7 & 34.7 \\
\hline $\mathrm{K}\left(\mathrm{g} \mathrm{kg}^{-1}\right)$ & $8.16 \pm 0.064$ & $7.5 \pm 0.05$ \\
\hline $\mathrm{P}\left(\mathrm{g} \mathrm{kg}^{-1}\right)$ & $4.72 \pm 0.64$ & n.d. \\
\hline $\mathrm{Ca}\left(\mathrm{g} \mathrm{kg}^{-1}\right)$ & $75.30 \pm 2.30$ & $56.3 \pm 0.24$ \\
\hline $\operatorname{Mg}\left(\mathrm{g} \mathrm{kg}^{-1}\right)$ & $9.08 \pm 0.23$ & $15.2 \pm 0.07$ \\
\hline $\mathrm{Na}\left(\mathrm{g} \mathrm{kg}^{-1}\right)$ & $5.46 \pm 0.09$ & $45.1 \pm 0.34$ \\
\hline $\mathrm{Fe}\left(\mathrm{g} \mathrm{kg}^{-1}\right)$ & $5.53 \pm 0.04$ & $3.0 \pm 0.03$ \\
\hline $\mathrm{B}\left(\mathrm{mg} \mathrm{kg}^{-1}\right)$ & $709 \pm 74$ & $2,5 \pm 61$ \\
\hline $\mathrm{Cu}\left(\mathrm{mg} \mathrm{kg}^{-1}\right)$ & $64.5 \pm 1.0$ & $55.5 \pm 0.1$ \\
\hline $\mathrm{Pb}\left(\mathrm{mg} \mathrm{kg}^{-1}\right)$ & $22.0 \pm 0.6$ & $13.5 \pm 0.0$ \\
\hline $\mathrm{Zn}\left(\mathrm{mg} \mathrm{kg}^{-1}\right)$ & $124 \pm 1.5$ & $66.9 \pm 0.1$ \\
\hline $\mathrm{Cr}\left(\mathrm{mg} \mathrm{kg}^{-1}\right)$ & $36.2 \pm 1.0$ & $18.8 \pm 0.1$ \\
\hline $\mathrm{Co}\left(\mathrm{mg} \mathrm{kg}^{-1}\right)$ & $3.72 \pm 0.08$ & n.d. \\
\hline $\mathrm{Cd}\left(\mathrm{mg} \mathrm{kg}^{-1}\right)$ & $3.36 \pm 0.11$ & $0.6 \pm 0.0$ \\
\hline $\mathrm{Ni}\left(\mathrm{mg} \mathrm{kg}^{-1}\right)$ & $28.6 \pm 1.3$ & $42 \pm 0.1$ \\
\hline $\operatorname{Mn}\left(\mathrm{mg} \mathrm{kg}^{-1}\right)$ & $221 \pm 4.9$ & $105 \pm 0.5$ \\
\hline
\end{tabular}

$E C$ electrical conductivity 
The degree of maturity was evaluated by biological methods involving seed germination and root length (Zucconi et al. 1981). Posidonia compost showed a good degree of maturity and the absence of phytotoxicity. Germination index values were greater than $96 \%$.

The physical and chemical characteristics of compost and mulch are reported in Table 1. The potential toxic elements were under the limits imposed by Italian legislation regulating compost quality (L 784/94; Dl 99/92). The two levels of compost were calculated according to total $\mathrm{N}$ concentration need: 109 and $218 \mathrm{~kg} \mathrm{~N} \mathrm{ha}^{-1}$ for OF10 and OF20, respectively. The supplied amounts of phosphorous $\left(\mathrm{P}_{2} \mathrm{O}_{5}\right)$ and potassium $\left(\mathrm{K}_{2} \mathrm{O}\right)$ were 84 and $75 \mathrm{~kg} \mathrm{ha}^{-1}$ in OF10 and 168 and $150 \mathrm{~kg} \mathrm{ha}^{-1}$ in OF20, respectively.

\subsection{Agro-techniques}

For each crop, the soil was plowed 4 weeks before transplanting to depth of $30 \mathrm{~cm}$; it was fertilized with posidonia compost or mineral fertilizers (ammonium sulfate, mineral perphosphate, and potassium sulfate, at rates of 110,120 , and $150 \mathrm{~kg} \mathrm{ha}^{-1}$ of $\mathrm{N}, \mathrm{P}$, and $\mathrm{K}$, respectively) and harrowed in order to break up soil clods into smaller pieces for transplanting bed. In the same time, the compost was spread to OF plots and buried with a rotary hoe, while organic mulching with beached posidonia residues was made at the same day of crop transplanting. The $\mathrm{N}$ fertilizer was applied half in pretransplanting and the remaining part after transplanting, in according to the fertilization program used in the area.

In the first field experiment, transplantation of tomato seedlings was made on 24 May 2011 and the harvest on 18 August. In the second experiment, transplantation of lettuce seedlings was made on 3 November and harvest on 17 March 2012. In both experiments, seeds were sown in polystyrene trays in a commercial nursery (Co.Vi.Ser. Srl, Arnesano, Lecce, Italy) and seedlings were transplanted into the field after 1 month with $1.0 \times 0.5-\mathrm{m}$ spacing for tomato and $0.50 \times 0.25 \mathrm{~m}$ for lettuce, leading to a plant density of 20.000 and 80.000 plants ha ${ }^{-1}$ for tomato and lettuce, respectively.

Irrigation and phytosanitary treatments followed the standard agronomic practice used in the area. In particular, irrigation was performed by a drip irrigation system twice per week, in the case of tomato, and once per week for lettuce. The water amount lost by the crops in the intervals between two successive irrigations was calculated according the FAO56 handbook (Allen et al. 1998). This method avoided that crops experienced any soil water stresses during their cycles. Soil moisture was monitored in the soil profile of two treatments: mulched and non-mulched soil (MF) by the installation of four moisture probes with capacitive sensors, $10 \mathrm{~cm}$ in length, based on the FDR technique, linked to automated data loggers (EM50; Decagon Devices Inc.). Soil moisture sensors were installed into the soil before the tomato transplanting at two depths: 20 and $35 \mathrm{~cm}$ from the soil surface. The purpose of these automated sensors was to measure the dielectric constant of the soil in order to find its volumetric water content with $\pm 2 \%$ accuracy.

Herbicide applications of benfluralin and propyzamide were performed in non-mulched plots immediately before transplanting of tomato and lettuce for controlling the weeds. Mulching soil plots did not receive any herbicide treatment.

\subsection{Determinations on posidonia, soil, and vegetal samples}

Soil samples were collected on 20 April 2011, before compost and mineral fertilization, and on 18 March 2012 (second crop harvest) at a depth of $0-20 \mathrm{~cm}$. The following parameters were determined: $\mathrm{EC}, \mathrm{pH}$, Kjeldahl N, available P, exchangeable cations $\left(\mathrm{Na}^{+}, \mathrm{K}^{+}, \mathrm{Ca}^{2+}, \mathrm{Mg}^{2+}\right)$, and cation exchange capacity.

During the first experiment, in summer, soil moisture was determined in the soil of both mulched and non-mulched plots.

Tomato and lettuce were harvested when the commercial size was attained. Representative marketable products were sampled randomly from each plot, in order to determine the effect of treatments on yield.

Antioxidants with nutritional and health values, lycopene, $\beta$-carotene, lutein, and $\alpha$-tocopherol were determined in tomato fruits as well as dry matter, total soluble solids, and titratable acidity, while dry matter and nitrate content were determined in lettuce.

The dry matter and total soluble solids were determined on the ripe fruits collected on the second (the final) truss. Titratable acidity was determined on fruits homogenized at $1000 \times \mathrm{g}$. Tomato fruits and lettuce leaves were dried to a constant weight in a forced draft oven at $65{ }^{\circ} \mathrm{C}$ for determination of the dry weight. Total soluble solids were determined using a portable reflectometer (Brixstix BX $100 \mathrm{Hs}$; Techniquip Corporation, Livermore, CA, USA). Acidity was determined by potentiometric titration with $0.1 \mathrm{M} \mathrm{NaOH}$ to $\mathrm{pH} 8.1$, using $10 \mathrm{ml}$ of juice. Results were expressed as the percentage of citric acid in the juice.

\subsection{Analytical methods}

\subsubsection{Chemical characteristics of posidonia fresh residues}

$\mathrm{EC}$ and $\mathrm{pH}$ were analyzed in drainage water using a ratio water/posidonia 1:1 $(v / v)$. The washing waters were analyzed for major inorganic cations and anions using an ion chromatograph (Dionex Model DX 120, Dionex Corp., Sunnyvale, CA, USA) equipped with a conductivity detector and a selfregeneration suppressor (Dionex ASRS-1). Chloride was measured with IonPac AS14 column and IonPac AG14 precolumn. $\mathrm{Na}_{2} \mathrm{CO}_{3}(1.8 \mathrm{mmol})-\mathrm{NaHCO}_{3}(1.7 \mathrm{mmol})$ 
solution was used as mobile phase. Sodium was determined using IonPac CS12A column and IonPac CG12A precolumn (DIONEX) with a methyl sulfonic acid solution $(18 \mathrm{mmol})$ as the mobile phase.

\subsubsection{Soil analysis}

The $\mathrm{pH}$ and electrical conductivity (EC) were determined in a 1:2.5 $(w / v)$ soil/water extract. The nitrogen content was determined by the Kjeldahl digestion, available $\mathrm{P}$ using the Olsen method, and total oxidizable organic C (Cox) using the Walkley and Black method, while $\mathrm{BaCl} 2$-triethanolamine method was used for determining cation exchange capacity (CEC) and exchangeable cations. The cations extracted were analyzed by an atomic absorption spectrophotometry (GBC 932 plus; GBC, Sydney, Australia).

\subsubsection{Extraction of E vitamin and carotenoids from tomato fruits}

Tomato fruits lyophilized were frozen in liquid nitrogen and ground in a mortar. Vitamin E and carotenoids were extracted simultaneously from $1 \mathrm{~g}$ of fine powder with an extraction solution containing $2 \mathrm{~mL}$ of $\mathrm{KOH}(60 \%), 2 \mathrm{~mL}$ of absolute ethanol, $1 \mathrm{~mL}$ of $\mathrm{NaCl}(1 \%)$, and $5 \mathrm{~mL} 0.05 \%$ butylated hydroxytoluene (BHT) in acetone. The tubes were incubated at $60{ }^{\circ} \mathrm{C}$ for $30 \mathrm{~min}$ and then cooled in ice water. After extraction with $n$-hexane-ethyl acetate ( $9: 1$ by vol), the tubes were centrifuged $5 \mathrm{~min}$ at $3000 \mathrm{rpm}$ and the upper phase, containing vitamin $\mathrm{E}$ and isoprenoids, was collected and transferred on a Rotavapor. The residue was dissolved in $3 \mathrm{~mL}$ of ethyl acetate, filtered through a $0.45-\mu \mathrm{m}$ syringe filter (Millipore, Corporation, Billerica, Ma, USA), and assayed by HPLC as described below.

\subsubsection{HPLC analysis of E vitamin and carotenoids}

HPLC analyses were carried out using an Agilent 1100 Series HPLC system as described by Fraser et al. (2000) but slightly modified. Carotenoids were separated using a reverse-phase C30 column $(5 \mu \mathrm{m}, 250 \times 4.6 \mathrm{~mm})$ (YMC Inc., Wilmington, NC, USA) with mobile phases consisting of methanol (A), $0.2 \%$ ammonium acetate aqueous solution/methanol (20/80 $v / v)(\mathrm{B})$, and tert-methyl butyl ether (C). The isocratic elution was as follows: $0 \mathrm{~min}, 95 \% \mathrm{~A}$ and $5 \% \mathrm{~B} ; 0$ to $12 \mathrm{~min}, 80 \%$ $\mathrm{A}, 5 \% \mathrm{~B}$, and $15 \% \mathrm{C} ; 12$ to $42 \mathrm{~min}, 30 \% \mathrm{~A}, 5 \% \mathrm{~B}$, and $65 \%$ $\mathrm{C}$; 42 to $60 \mathrm{~min}, 30 \% \mathrm{~A}, 5 \% \mathrm{~B}$, and $65 \% \mathrm{C}$; and 60 to $62 \mathrm{~min}, 95 \% \mathrm{~A}$ and $5 \% \mathrm{~B}$. The column was re-equilibrated for $10 \mathrm{~min}$ between runs. The flow rate was $1.0 \mathrm{~mL} / \mathrm{min}$, and the column temperature was maintained at $25^{\circ} \mathrm{C}$. The injection volume was $10 \mathrm{~mL}$. Absorbance was registered by diode array at wavelengths of $475 \mathrm{~nm}$. Carotenoids were identified by comparing their retention times and UV-vis spectra to authentic standards.

The determination of vitamin $\mathrm{E}$ was based on the analytical column Phenomenex C18 $(250 \mathrm{~mm} \times 4.60 \mathrm{~mm})$, and methanol $(98 \%, v / v)$ was used as mobile phase. The $\alpha$-tocopherol content was calculated by means of standard calibration curves. Tocopherol and carotenoids standards were purchased from Sigma-Aldrich (Milan, Italy) and Extrasynthese (Genay CEDEX, France), respectively.

\subsubsection{Extraction and analysis of nitrate from lettuce leaf}

Dry material was finely ground and used for quantitative chemical analyses of nitrate $\left(\mathrm{NO}_{3}{ }^{-}\right)$. For this purpose, $0.5 \mathrm{~g}$ of dry sample (edible portion) was treated with $50 \mathrm{~mL}$ of carbonate $(1.8 \mathrm{mM})$ and sodium bicarbonate $(1.7 \mathrm{mM})$ solution and determined by ion chromatography. The solvent used for extraction was also used as eluent.

\subsection{Data analysis}

Dataset was submitted to ANOVA and followed by least significant difference test (LSD) post hoc for significant values. Values of $P \leq 0.05$ were considered statistically different. Standard deviation (SD) was calculated. All the data were performed with the general linear model (GLM) routine of the Statistical Analysis System (SAS Institute Inc 1999).

\section{Results and discussion}

\subsection{Physicochemical properties of posidonia residues}

The electrical conductivity (EC) measured in water drainage was high after the first washing (7.48 and $6.86 \mathrm{dS} \mathrm{m}^{-1}$ for San Cataldo and Sant'Isidoro, respectively). $\mathrm{Na}^{+}$and $\mathrm{Cl}^{-}$were the ions detected in greater amount $(1220$ and $1915 \mathrm{mg} / \mathrm{L}$, respectively), while at lower concentrations, calcium $\left(\mathrm{Ca}^{2+}\right)$ and magnesium $\left(\mathrm{Mg}^{2+}\right)$ (559 and $142 \mathrm{mg} / \mathrm{L}$, respectively) were found. All these ions were removed by the second washing, and a decrease of $60 \%$ of the initial value of EC was observed for both the sites. However, after four washings, posidonia residues showed a EC value equal to that of many composts used in agriculture $\left(1.20 \mathrm{dS} \mathrm{m}^{-1}\right)$ and low concentrations of $\mathrm{Na}^{+}$and $\mathrm{Cl}^{-}(108$ and $163 \mathrm{mg} / \mathrm{L}$, respectively).

The dynamics of removal of salts just described is in accordance with the findings of Parente et al. (2013), even if the amount of salts initially present on the leaves varies according to age and origin of the residue. Parente et al. (2013) reported that the removal of the salts from the residues of posidonia can also occur in a natural way through the rains, keeping the material on an open-air space and turning it. 
Table 2 Effect of posidonia compost (OF), posidonia mulch (mulched), and mineral fertilizer (MF) on soil characteristics at the end of the cropping cycle (after the lettuce harvesting)

\begin{tabular}{llllllllll}
\hline Treatments & $\mathrm{pH}$ & $\left.\mathrm{EC}(\mathrm{dS} \mathrm{m})^{-1}\right)$ & $\mathrm{N}$ total (Kjeldahl) $\%$ & Available $\mathrm{P}$ & $\begin{array}{l}\mathrm{K} \\
\left(\mathrm{mg} \mathrm{kg}^{-1}\right)\end{array}$ & $\mathrm{Na}$ & $\mathrm{Mg}$ & $\mathrm{Ca}\left(\mathrm{g} \mathrm{kg}^{-1}\right)$ & $\mathrm{CEC}\left(\mathrm{cmol} \mathrm{kg}^{-1}\right)$ \\
\hline OF10 & 7.49 & $0.30 \mathrm{ab}$ & 0.13 & $10.6 \mathrm{bc}$ & $160 \mathrm{~b}$ & 424 & 120 & 3.00 & 17.3 \\
OF20 & 7.46 & $0.33 \mathrm{a}$ & 0.14 & $13.1 \mathrm{a}$ & $216 \mathrm{a}$ & 528 & 130 & 3.44 & 20.0 \\
MF & 7.56 & $0.26 \mathrm{~b}$ & 0.10 & $9.3 \mathrm{c}$ & $112 \mathrm{~d}$ & 472 & 150 & 3.07 & 18.7 \\
Mulched & 7.63 & $0.35 \mathrm{a}$ & 0.13 & $11.8 \mathrm{ab}$ & $144 \mathrm{c}$ & 496 & 160 & 2.75 & 16.5 \\
Significance & $\mathrm{ns}$ & $*$ & $\mathrm{~ns}$ & $*$ & $* * *$ & $\mathrm{~ns}$ & $\mathrm{~ns}$ & $\mathrm{~ns}$ & $\mathrm{~ns}$ \\
\hline
\end{tabular}

Values followed by the same letter in the same column do not differ significantly $(P=0.05)$

OF10 compost seagrass $10 \mathrm{Mg} \mathrm{ha}^{-1}$, OF20 compost seagrass $20 \mathrm{Mg} \mathrm{ha}^{-1}, M F$ mineral fertilization, mulched organic mulch with fresh seagrass, $E C$ electrical conductivity, $n s$ not significant

* Significant at the $5 \%$ level of probability

$* * *$ Significant at the $0.1 \%$ level of probability

Therefore, the temporary storage and exposure to the washing action of the rain could be used as sustainable practices in order to reduce the presence of salts in the material and make it suitable for composting.

\subsection{Soil physical chemical properties}

At the end of the second crop (lettuce), the organic mulch and compost had noticeable effects on certain soil chemical properties. Mean values of soil $\mathrm{pH}$ after cropping did not show any effect caused by the application of organic amendments (Table 2). On average, the soil EC was lower in the plots fertilized with the mineral fertilizer compared to those who received the residues of posidonia. Significant differences were also observed for potassium: $\mathrm{K}$ content in the soil increased with increasing amount of added compost. This result emphasizes the importance of posidonia-based compost as a potential source of $\mathrm{K}$ for vegetable production. In addition, the application of organic mulch and compost increased plant available $\mathrm{P}$ in the soil. This result is in accordance with some authors (Odlare et al. 2008; Fagnano et al. 2011), who found that plant available $\mathrm{P}$ increased in plots treated with organic amendments. Organic P in composts from plant materials is readily decomposed to release orthophosphate, which is available to plants (He et al. 2001). In addition, Hue and Sobieszczyk (1999) reported that organic amendments, such as yard waste compost and biosolids, can enrich the soil $\mathrm{P}$ status by their direct contribution and by alteration of the soil $\mathrm{P}$ sorption capacity. At the end of the experiment, mean values of Kjeldahl $\mathrm{N}$ and CEC in all plots were higher than those detected at the start of the study (Tables 1 and 2). Especially noticeable was the increase of Kjeldahl $\mathrm{N}$ in plots fertilized with $20 \mathrm{Mg} \mathrm{ha}^{-1}$ of compost ( 0.14 vs. $0.07 \%$ ), although differences compared to the control and mulch were not significant (Table 2). This result shows high available $\mathrm{N}$ of posidonia compost as observed by Mininni et al. (2013) in a previous study in which posidonia compost was used as growing media for transplant production. However, compost fertilization and posidonia mulch did not increase soil organic matter, because of low levels of these materials added during the experiment. Some authors argued that the buildup of organic matter in soils is a process much slower and more complex than its decline (Diacono and Montemurro 2010). Sandy soils occasionally responded to amendments of organic material (Sikora and Yakovchenko 1996), and the increase in organic matter content can occur after long-term repeated application of organic amendments (Diacono and Montemurro 2010).

Posidonia on the soil served as a barrier against water losses. Volumetric water content was monitored in tomato growing cycle. Posidonia offshore residues at the soil surface shaded the soil and attenuated the soil evaporation. However, the soil water status of the first soil layer, detected by the probe buried at $-20-\mathrm{cm}$ depth, is constantly lower than that of the deeper layer, detected by the probe at $-35-\mathrm{cm}$ depth. Data from the $-20-\mathrm{cm}$ probes do not show clearly the difference in soil moisture due to the presence of the organic mulch. Differences in soil water status appeared in measurements on the deeper layer, where is localized most of the root system of both species. In the case of the mulched soil, the soil water content (at $-35 \mathrm{~cm}$ in depth) is $10 \%$ higher than the tomato crop without posidonia mulching.

This result is in accordance with Ji and Unger (2001) and Campiglia et al. (2011) who found that straw mulch increased soil moisture storage. This higher quantity (10\%), measured in the most rooted soil layer, contributes to prevent the tomato from water stress, which is frequent under Mediterranean conditions.

\subsection{Tomato yield and antioxidant content}

No phytotoxicity symptoms were observed in any of the plant fertilized with posidonia compost or mulched with fresh 


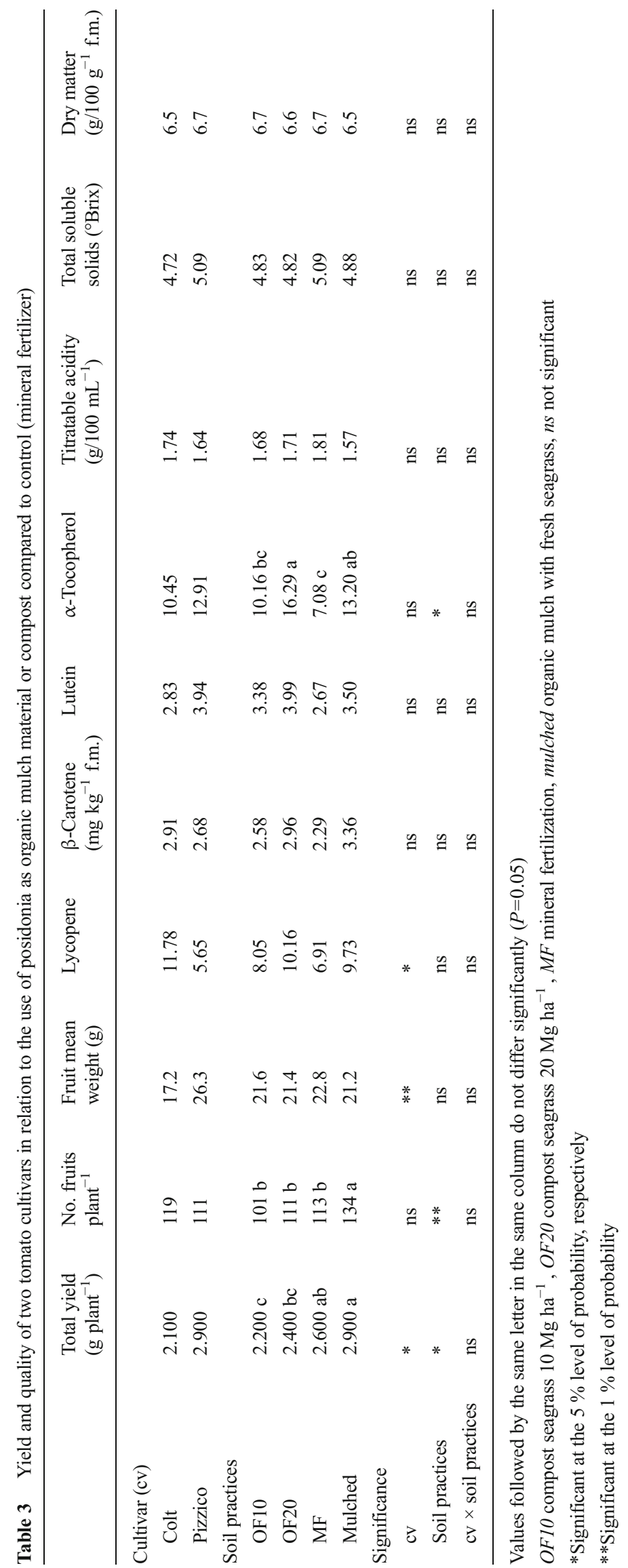


leaves beached of this marine plant, and the same growth rate was observed in all plots.

'Pizzico' produced more than 'Colt' having berries larger (Table 3). The highest marketable fruit yield was obtained with the mulched soil, while the lowest with the lower compost dose. The plants of the mulched plots with posidonia offshore residues showed the highest number of fruits, while no effect of experimental treatments was observed on the average fruit weight. In an analogous study conducted by Campiglia et al. (2011), the use of legume cover crops converted into mulches increased tomato yield. The increase in tomato yield in the mulching treatments may be attributed to reduction in water loss through evaporation from soil surface and to improvement in moisture storage. This is of special importance in sandy soils, as these soils generally have low water holding capacity. In addition, surface mulching enhanced better control of weeds compared to the non-mulching treatments.

Some papers report low level of net $\mathrm{N}$ mineralization for yard composts, averaging only 1-3\% in the first year (Hartz et al. 1996; Hartz and Giannini 1998). The low mineralization rates measured by these Authors suggest that high levels of yard compost should be added in order to achieve yields equal to those under conventional production. This is confirmed in our experiment by the second level of compost $\left(20 \mathrm{Mg} \mathrm{ha}^{-1}\right)$ incorporated into soil, which was adequate to satisfy the nutrient requirements of tomato.

As regard the quality features of tomato fruits, dry matter, total soluble solids, titratable acidity, and carotenoids were not influenced by the experimental treatments. The average content of solid soluble was of $4.9^{\circ} \mathrm{Brix}$; this value coincided with those found by George et al. (2004) who analyzed different cultivars of tomatoes. 'Colt' showed a concentration of lycopene in the fruits higher than that found in 'Pizzico,' because smaller berries have more lycopene than the larger ones (Serio et al. 2006; Pernice et al. 2010. Lycopene levels observed in the present study were highly variable and lower than those found by authors cited above. Some authors reported that the content of lycopene depends on several factors including genotype and environmental conditions (temperature and light) and may be affected by factors such as the portion of the pulp and the irregular distribution in the sample (Serio et al. 2006). Instead, $\beta$-carotene and lutein were similar in fruits of both the cultivar and these values were equal to those detected by Tee and Lim (1991).

The $\alpha$-tocopherol content of fruits harvested from plants grown on the plots amended with $20 \mathrm{Mg} \mathrm{ha}^{-1}$ of posidonia compost was two times higher than MF. Moreover, values markedly higher of $\alpha$-tocopherol were also observed in the fruits harvested from mulched plots with respect to MF. In general, there is limited information in the literature on the effects of different fertilizers on the antioxidant components of tomatoes (Toor et al. 2006). A potential explanation of the remarkable difference in $\alpha$-tocopherol found in tomato fruits might be due to an increase of soil EC in OF20 and mulched plots (Table 2), induced by the addition of posidonia compost and fresh residues beached of this marine plant used as organic mulch material. This could induce, in tomato plants, the activation of specific metabolic pathways in response to moderate osmotic stress, whereas it did not seem to affect negatively the growth of the plants. Serio et al. (2004) observed in tomato plants grown in posidonia that the increase in $\mathrm{NaCl}$ in the nutrient solution induced an increase in vitamin $\mathrm{E}$ $(\alpha$-tocopherol) and vitamin $C$ (ascorbate plus dehydroascorbate). Due to the benefits of vitamin $\mathrm{E}$ in human diets, the increase in the $\alpha$-tocopherol content improved the nutritional value of the tomato fruits grown with posidoniabased compost and posidonia fresh residues.

\subsection{Lettuce yield and nitrate content}

Posidonia compost and mulch did not cause either an adverse effect on lettuce growth or phytotoxicity symptoms in plants. These observations confirmed the good quality of the compost used and the absence of high levels of $\mathrm{Na}^{+}$and $\mathrm{Cl}^{-}$in the mulch after washing (Table 4). Total yield of lettuce was lower in the plots fertilized with $10 \mathrm{Mg} \mathrm{ha}^{-1}$ of compost. Significant differences in $\mathrm{NO}_{3}, \mathrm{Cl}^{-}$, and sulfates $\left(\mathrm{SO}_{4}\right)$ between cultivars and treatments were founded. Cultivar Ribaï (red oak lettuce) showed the highest $\mathrm{NO}_{3}$ content in mulched and control plots (704 $\mathrm{mg} \mathrm{NO}_{3} \mathrm{~kg}^{-1}$ of fresh weight, on average), while the lower $\mathrm{NO}_{3}$ concentration was observed in the plots fertilized with compost (Fig. 2). 'Ribaï' accumulated more $\mathrm{NO}_{3}$ than 'Kipling' (green oak lettuce) when fertilized with mineral fertilizers or mulched with fresh beached leaves of posidonia, as a direct consequence of the different genotype. In any case, all values were much lower than the threshold laid down in the 1258/2011 European Directive (4000 mg NO $\mathrm{kg}^{-1}$ of fresh weight), confirming that vegetable production in the Mediterranean area does not have problems of $\mathrm{NO}_{3}$ accumulation in leaves (Santamaria 2006; Fagnano et al. 2011. This result is in agreement with findings of Pavlou et al. (2007) and Fagnano et al. (2011), which reported low concentrations of $\mathrm{NO}_{3}$ in the edible portions of lettuce fertilized with composts. In addition, $\mathrm{Cl}^{-}$was influenced by cultivar and treatment. 'Ribaï' showed the lowest content of $\mathrm{Cl}^{-}$in the plots fertilized with $20 \mathrm{Mg} \mathrm{ha}^{-1}$ of compost, while the plants mulched showed, on average, the highest value. A similar trend was observed also for 'Kipling,' although these differences were less remarkable.

The lower compost dose $\left(10 \mathrm{Mg} \mathrm{ha}^{-1}\right)$ was not sufficient to satisfy the nutrient requirements of lettuce. Posidonia compost, as other composts of different origin, has low concentration of nutrients in comparison with mineral fertilizer. Therefore, the compost application rate necessary to satisfy the complete nutritional requirement of vegetable crops is usually high, ranging $40-100 \mathrm{Mg} \mathrm{ha}^{-1}$ (Hornick et al. 1984). In this study, the dose of $20 \mathrm{Mg} \mathrm{ha}^{-1}$ was adequate and no 
Table 4 Yield and quality of two lettuce cultivars in relation to the use of posidonia as organic mulch material or compost compared to control (mineral fertilizer)

\begin{tabular}{|c|c|c|c|c|c|}
\hline & Total yield $\left(\mathrm{Mg} \mathrm{ha}^{-1}\right)$ & Dry matter (\%) & $\begin{array}{l}\text { Chloride content } \\
\text { (g } 100 \mathrm{~g}^{-1} \text { d.w.) }\end{array}$ & Sulfate content & $\begin{array}{l}\text { Nitrate content } \\
\text { (mg kg}{ }^{-1} \text { f.w.) }\end{array}$ \\
\hline \multicolumn{6}{|l|}{ Cultivar (cv) } \\
\hline Kipling & 12.2 & 4.8 & 3.1 & 0.26 & 533 \\
\hline Ribaï & 16.8 & 4.9 & 2.3 & 0.33 & 669 \\
\hline \multicolumn{6}{|l|}{ Soil practices } \\
\hline OF10 & $11.9 \mathrm{~b}$ & 4.8 & $2.4 \mathrm{~b}$ & $0.23 \mathrm{~b}$ & $542 \mathrm{~b}$ \\
\hline OF20 & $14.4 \mathrm{a}$ & 4.8 & $2.1 \mathrm{c}$ & $0.25 \mathrm{~b}$ & $453 \mathrm{c}$ \\
\hline MF & $16.5 \mathrm{a}$ & 5.0 & $3.0 \mathrm{a}$ & $0.37 \mathrm{a}$ & $707 \mathrm{a}$ \\
\hline Mulched & $15.1 \mathrm{a}$ & 4.7 & $3.1 \mathrm{a}$ & $0.29 \mathrm{~b}$ & $702 \mathrm{a}$ \\
\hline \multicolumn{6}{|l|}{ Significance } \\
\hline $\mathrm{cv}$ & ns & ns & $* *$ & $\mathrm{~ns}$ & $* *$ \\
\hline Soil practices & $* *$ & ns & $* * *$ & $* *$ & $* * *$ \\
\hline $\mathrm{cv} \times$ soil practices & ns & ns & $* *$ & ns & $* * *$ \\
\hline
\end{tabular}

Values followed by the same letter in the same column do not differ significantly $(P=0.05)$

OF10 compost seagrass $10 \mathrm{Mg} \mathrm{ha}^{-1}, O F 20$ compost seagrass $20 \mathrm{Mg} \mathrm{ha}^{-1}, M F$ mineral fertilization, mulched organic mulch with fresh seagrass, $n s$ not significant

**Significant at the $1 \%$ level of probability, respectively

*** Significant at the $0.1 \%$ level of probability

a

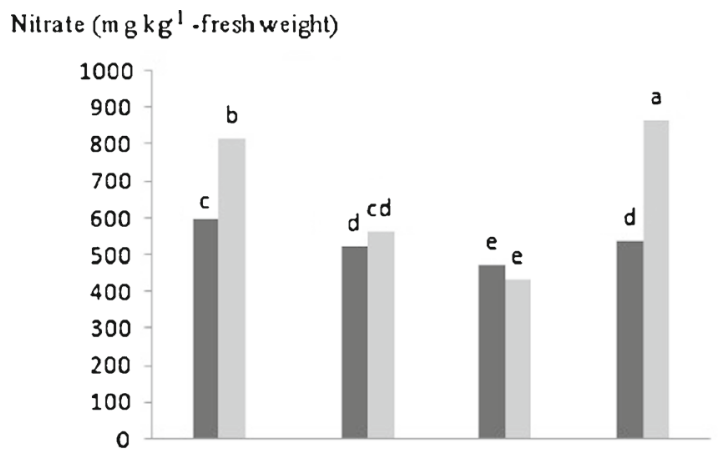

b

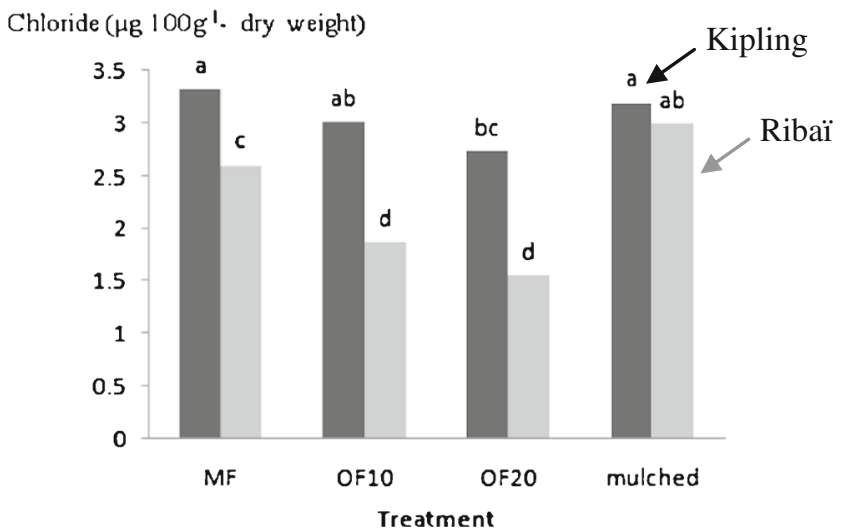

Fig. 2 Effect of treatments on the content of nitrate (a) and chloride (b) in two lettuce cultivars. Values followed by the same letter do not differ significantly $(P=0.05)$. OF10 compost seagrass $10 \mathrm{Mg} \mathrm{ha}^{-1}, O F 20$ compost seagrass $20 \mathrm{Mg} \mathrm{ha}^{-1}, M F$ mineral fertilization, mulched organic mulch with fresh seagrass differences in the yields were observed with the conventional fertilization. Therefore, the argument that organic farming is equivalent to conventional farming, as observed by González et al. (2010) is supported by our data.

This study also revealed that mulching can control the common annual weed species and improve soil moisture through reducing soil surface evaporation although the mulching effects may become less significant when soil moisture is high due to excessive raining (Prado and Airoldi 1999). As a mulch, posidonia has many advantages: the release of nutrients, the elimination of polyethylene plastic mulches, and the reduction in use of commercial herbicides. The use of posidonia fresh leaves as organic mulch can contribute to eliminate polyethylene plastic mulches and commercial herbicides. Therefore, the eliminations of these might contribute to lower the production cost in tomato and lettuce crop. The washing of residues can also take place storing for a long period the material under the action of rain and turned weekly in order to avoid putrefactive phenomena. Therefore, the only added cost is that of moving of this organic material.

\section{Conclusion}

The use of posidonia-based compost can contribute to improve the availability of nutrients in coastal agricultural soils in Mediterranean environments, which are particularly poor in 
organic matter and nutrients. The application of $20 \mathrm{Mg} \mathrm{ha}^{-1}$ of compost as a fertilizer had similar effects on nutritional status and yield of tomato and lettuce to those caused by the inorganic fertilizer. Composting of posidonia and its use in agriculture as organic mulch material would seem to be a potentially effective way of recycling this beached waste and an innovative way of obtaining low-cost fertilizers and with a low environmental impact which could be used in integrated sustainable vegetable production systems.

Acknowledgments This work has been supported by project Life09 ENV/IT/000061 "Posidonia Residues Integrated Management for Ecosustainability" (P.R.I.M.E.) co-financed by the European Commission. We would like to thank Leone D'Amico, Emiliano Gira, Giovanni Lacolla, Salvatora Maria Giausa, and Cosimo Fina for their help in running the experiment.

\section{References}

Abdul-Baki AA, Teasdale JR, Korcak R, Chitwood DJ, Huettel RN (1996) Fresh-market tomato production in a low-input alternative system using cover-crop mulch. Hort Sci 31:65-69

Allen RG, Pereira LS, Raes D, Smith M (1998) Crop evapotranspiration. Guidelines for computing crop water requirements-FAO. Irrigation and drainage paper NO 56, FAO, Rome

Bilalis D, Sidiras N, Economou G, Vakali C (2003) Effect of different levels of wheat straw soil surface coverage on weed flora in Viciafaba crops. J Agron Crop Sci 189:233-241. doi:10.1046/j. 1439-037X.2003.00029.x

Bulluck LR, Brosius M, Evanylo GK, Ristaino JB (2002) Organic and synthetic fertility amendments influence soil microbial, physical and chemical properties on organic and conventional farms. Appl Soil Ecol 19:147-160. doi:10.1016/S0929-1393(01)00187-1

Campiglia E, Mancinelli R, Radicetti E, Caporali F (2010) Effect of cover crops and mulches on weed control and nitrogen fertilization in tomato (Lycopersicon esculentum Mill.). Crop Prot 29:354-363. doi:10.1016/j.cropro.2009.12.001

Campiglia E, Mancinelli R, Radicetti E (2011) Influence of no-tillage and organic mulching on tomato (Solanum Lycopersicum L.) production and nitrogen use in the mediterranean environment of central Italy. Sci Hortic 130:588-598. doi:10.1016/j.scienta.2011.08.012

Castaldi P, Melis P (2002) Composting of Posidoniaoceanica and its use in agriculture. In: Insam H, Riddech N, Klammer S (eds) Microbiology of composting. Springer, Berlin Heidelberg, pp 425-434

Castaldi P, Garau G, Melis P (2004) Influence of compost from sea weeds on heavy metal dynamics in the soil-plant system. Fresen Environ Bull 13:1322-1328

Diacono M, Montemurro F (2010) Long-term effects of organic amendments on soil fertility. A review. Agron Sustain Dev 30:401-422. doi:10.1051/agro/2010034

Fagnano M, Adamo P, Zampella M, Fiorentino N (2011) Environmental and agronomic impact of fertilization with composted organic fraction from municipal solid waste: a case study in the region of Naples, Italy. Agr Ecosyst Environ 141:100-107. doi:10.1016/j.agee.2011.02.019

Fraser PD, Pinto MES, Holloway DE, Bramley PM (2000) Application of high-performance liquid chromatography with photodiode array detection to the metabolic profiling of plant isoprenoids. Plant J 24:551-558. doi:10.1111/j.1365-313X. 2000.00896.x
George B, Kaus C, Khurduja DS, Kapoor HC (2004) Antioxidants in tomato (Lycopersicon esculentum) as a function of genotype. Food Chem 84:45-51. doi:10.1016/S0308-8146(03)00165-1

González M, Gomez E, Comese R, Quesada M, Conti M (2010) Influence of organic amendments on soil quality potential indicators in an urban horticultural system. Bioresour Technol 101:8897-8901. doi:10.1016/j.biortech.2010.06.095

Hartz TK, Giannini C (1998) Duration of composting of yard wastes affects both physical and chemical characteristics of compost and plant growth. Hort Sci 33:1192-1196

Hartz TK, Costa FJ, Schrader WL (1996) Suitability of composted green wastes for horticultural uses. Hort Sci 31:961-964

He Z, Yang X, Kahn BA, Stoffella PJ, Calvert DV (2001) Plant nutrition benefits of phosphorus, potassium, calcium, magnesium, and micronutrients from compost utilization. In: Stoffela PJ, Kahn BA (ed) Compost utilization in horticultural cropping systems, CRC Press, Boca Raton

Hornick S, Sikora L, Sterrett S, Murray J, Millner P, Parr J, Chaney R, Wilson G (1984) Utilization of sewage sludge compost as soil conditioner and fertilizer for plant growth. Agricul Inform Bull No. 464. U.S.D.A. U.S. Printing Office, Washington

Hue NV, Sobieszczyk BA (1999) Nutritional values of some biowastes as soil amendments. Compost Sci Util 1:34-41. doi:10.1080/ 1065657X.1999.10701950

Ji S, Unger PW (2001) Soil water accumulation under different precipitation, potential evaporation, and straw mulch conditions. Soil Sci Soc Am J 65:442-448. doi:10.2136/sssaj2001.652442x

Kirkman H, Hendrick GA (1997) Ecological significance and commercial harvesting of drifting and beach-cast macroalgae and seagrasses in Australia: a review. J Appl Phycol 9:311-326. doi:10.1023/ A:1007965506873

Kouki S, Saidi N, Ben Rajeb A et al (2012) Control of fusarium wilt of tomato caused by Fusariumoxysporum f. sp. radicis-lycopersici using mixture of vegetable and Posidoniaoceanica compost. Appl Environ Soil Sci 12:1-6. doi:10.1155/2012/239639

Mininni C, Bustamante MA, Medina E, Montesano F, Paredes C, PérezEspinosa A, Moral R, Santamaria P (2013) Evaluation of posidonia seaweed-based compost as a substrate for melon and tomato seedling production. J HorticSci Biotech 88:345-351

Montemurro F, Maiorana M (2007) Nitrogen utilization, yield, quality and soil properties in a sugarbeet crop amended with municipal solid waste compost. Compost Sci Util 15:84-92. doi:10.1080/ 1065657X.2007.10702317

Montemurro F, Convertini G, Ferri D, Maiorana M (2005) MSW compost application on tomato crops in Mediterranean conditions: effects on agronomic performance and nitrogen utilization. Compost Sci Util 13:234-242. doi:10.1080/1065657X.2005.10702247

Ochieng CA, Erftemeijer PL (1999) Accumulation of seagrass beach cast along the Kenyan coast: a quantitative assessment. Aquat Bot 65: 221-238. doi:10.1016/S0304-3770(99)00042-X

Odlare M, Pell M, Svensson K (2008) Changes in soil chemical and microbiological properties during 4 years of application of various organic residues. Waste Manag 28:1246-1253. doi:10.1016/j. wasman.2007.06.005

Parente A, Montesano F, Lomoro A, Guido M (2013) Improvement of beached Posidonia residues performance to composting. Environ Eng Manag J 12:81-84

Pavlou GC, Ehaliotis CD, Kavvadias VA (2007) Effect of organic and inorganic fertilizers applied during successive crop seasons on growth and nitrate accumulation in lettuce. Sci Hortic-Amsterdam 111:319-325. doi:10.1016/j.scienta.2006.11.003

Pernice R, Parisi M, Giordano I et al (2010) Antioxidants profile of small tomato fruits: effect of irrigation and industrial process. SciHorticAmsterdam 126:156-163. doi:10.1016/j.scienta.2010.06.021 
Pinamonti F (1998) Compost mulch effects on soil fertility, nutritional status and performance of grapevine. Nutr Cycl Agroeceosys 51: 239-248. doi:10.1023/A:1009701323580

Prado AGS, Airoldi C (1999) The influence of moisture on microbial activity of soils. Thermochim Acta 332:71-74. doi:10.1016/S00406031(99)00062-3

Rice PJ, McConnell LL, Heighton LP et al (2001) Runoff loss of pesticides and soil: a comparison between vegetative mulch and plastic mulch in vegetable production system. J Environ Qual 30: 1808-1821. doi:10.2134/jeq2001.3051808x

Santamaria P (2006) Nitrate in vegetables: toxicity, content, intake and EC regulation. J Sci Food Agr 86:10-17. doi:10.1002/jsfa.2351

SAS Institute Inc., (1999) SAS/STAT User's Guide, Version 8, Cary, NC. SAS Institute Inc

Serio F, De Gara L, Carretto S, Leo L, Santamaria P (2004) Influence of an increased $\mathrm{NaCl}$ concentration on yield and quality of cherry tomato grown in posidonia (Posidonia oceanica (L) Delile). J Sci Food Agric 84:1885-1890. doi:10.1002/jsfa. 1883
Serio F, Ayala O, Bonasia A, Santamaria P (2006) Antioxidant properties and health benefits of tomato. In: Govil JN, Sing VK, Arunachalhm C (eds) Recent progress in medicinal plants. Search for natural drugs. Studium Press, Houston, pp 163-183

Sikora LJ, Yakovchenko V (1996) Soil organic matter mineralization after compost amendment. Soil Sci Soc Am J 60:1401-1404. doi: 10.2136/sssaj1996.03615995006000050015x

Tee E, Lim CL (1991) Carotenoid composition and content of Malaysian vegetables and fruits by the AOAC and HPLC methods. Food Chem 41:309-339. doi:10.1016/0308-8146(91)90057-U

Toor RK, Savage GP, Heeb A (2006) Influence of different types of fertilisers on the major antioxidant components of tomatoes. J Food Comp Anal 19:20-27. doi:10.1016/j.jfca.2005.03.003

Tu C, Ristaino JB, Hu S (2006) Soil microbial biomass and activity in organic tomato farming systems: effects of organic inputs and straw mulching. Soil Biol Biochem 38:247-255. doi:10.1016/j.soilbio.2005.05.002

Zucconi F, Pera A, Forte MV, De Bertoldi M (1981) Evaluating toxicity of immature compost. Biocycle 22:54-57 